\title{
The politics of localization: controlling movement in the
}

\section{field.}

\author{
Akbar Keshodkar (Institute of Social and Cultural Anthropology, \\ University of Oxford)
}

Romantic notions of the field, as depicted in works such as those of Evans-Pritchard and Malinowski, where an anthropologist is able to set up a hut in the middle of a village, conceal the complexities encountered by researchers in attempts to localize themselves in the field. In the post-colonial, globalizing world today, the field is marked by various unequal power relationships. Reflecting on my fieldwork experience I shall examine how questions of race and ethnicity affect a researcher's ability to acquire various apprenticeships for understanding how 'things are done' (Jenkins 1994: 442) and effectively conduct fieldwork. I worked in the ethnically divided society of Zanzibar, where I was categorized as a local Asian and my ability to move through the social landscape was tied to my ethnic origins. Placed within such contested landscapes, where the researcher becomes a part of the politicized field, traditional training in fieldwork methodology proves useless. In such situations, the researcher is required to re-examine approaches to fieldwork and re-evaluate their position vis-à-vis the rest of the community. As ethnic/racial categories through which the locals classify the researcher dictate the nature of data collected, the paper will explore issues that a researcher must attempt to comprehend when placed in such a situation and discuss how questions of power are integral for negotiating one's position in such a politicized field.

\section{Introduction}

Fieldwork is characterized by a series of apprenticeships, which, over time, enable the researcher to understand the values, categories, and practices that order how things are done (Jenkins 1994: 442). These apprenticeships evolve on the basis of how researchers are able to identify themselves or are identified by the local community. The perceived and/or performed identity assigned to the researcher affects their ability to move through the local landscape (Keshodkar 2004), the relationships they develop with respondents and the apprenticeships they are able to acquire in the field. During the first two thirds of the twentieth century, colonial rule and the institutions they left behind (primarily in the industrializing world) facilitated the movement of specific researchers, namely white, western males, enabling them to establish a particular local place. They were thus in a position to access and control the nature of their apprenticeships in the field. Today, however, in a post-colonial setting and in an increasingly globalizing world, aspects of race and ethnicity associated with the researchers vis-á-vis the community in which the research is carried out dictate the extent to which they are able to influence the kind of identity they will acquire within the local landscape. Power once consolidated in the centre is also now exercized at the margins in different forms (cf. Hetherington 1996: 34) and those marginalized today have acquired the ability to control the spaces in which the researchers can move and consequently, the nature of their apprenticeships. Before moving further, I must 
emphasize that along with questions of race and ethnicity, the issue of gender is also equally, if not more important, in regulating the spaces in which a researcher can move. However, in light of my particular experience in the field, this paper shall only focus on how questions of race and ethnicity can affect the researcher's ability to become 'localized' and the nature of various apprenticeships that can be acquired in the field.

\section{Identity constructions in Zanzibar}

The identity discourse in Zanzibar, Tanzania, has been shaped by the movement of people to and from the isles for over two millenniums. Social processes that have historically facilitated this movement include the maritime Indian Ocean trade, Arab military conquest, transportation of slaves from mainland Africa, and British colonial rule. In recent memory, the 1964 revolution led to the expulsion of many non-African minorities from the isles by those claiming Zanzibar for Africa. Only after the abandonment of the socialist experiment and the liberalization of the economy in the mid 1980s have many of the minorities re-acquired the means to move through the landscape. Today, Zanzibar continues to flourish as an ethnically and racially diverse, yet segregated society, composed of Arabs, Asians, Comorians, Pembans, and Swahilis who all identify themselves as Zanzibaris. The construction of this identity, produced by a history of inequalities between these different groups, has given rise to different social experiences and meanings within the local population. It is within this politically contested landscape that I conducted my fieldwork in 2001 and 2002.

The aim of my fieldwork was to investigate the impact of the newly developing tourism industry on constructions of the Zanzibari identity discourse, and so the nature of the project necessitated me to interact with Zanzibaris of various ethnicities. However, within weeks of arriving in Zanzibar, I had to accept the harsh reality of local identity politics, of which I was unaware before entering the field. Despite being an Asian-American Muslim, I was perceived and identified as a Zanzibari Asian by local Asians, non-Asian Zanzibaris and tourists visiting Zanzibar. Consequently, I could (initially) only move through social spaces in which local Asians, who today make up less than one percent of the population, possessed social centrality. The religious and communal orientation of the Asian minority in East Africa have served as essential determinants of their way of life in this part of the world, and in the process, created a social distance from the rest of the local population (Gregory 1993a: 34). Confronted by exceptional forces of social change in East Africa, these migrants from India acted to strengthen their communal ties in order to preserve their cultural identities (Gregory 1993b: 19). However, this dedication to their religious community, which continues today, and has shaped their economic and social practices, had not been appreciated by members of other racial communities in Zanzibar and has led them to categorize the Asians as being selfish and greedy, committed only to their individual needs and those of their specific communities (see Larsen 2004: 134). While the majority of Asian Zanzibaris share the identity of being both Muslim and Zanzibari, with the rest of the local population, these common identities are secondary to questions of race and ethnicity. Being a Muslim and an Asian American, I found that greater emphasis was laid on my identity as an Asian in most of my social interaction with non-Asian Zanzibaris. However, in order to conduct my research on how tourism shaped the identities of Swahili and Asian Zanzibaris I needed to interact more with Swahili Zanzibaris. In recent years, many of 
them have started to work in hotel environments and are more involved with tourists, but the presence of these ethnic and racial tensions restricted my ability to proceed effectively with the fieldwork.

\section{Acquiring apprenticeships as a local Asian}

The tradition of fieldwork in anthropology emphasizes the study of social change within a given environment over an extended period of time. In order to understand carefully and evaluate the implicit meanings embedded in different forms of human life, it is necessary for the field researcher to engage closely with people to grasp the connections that define a particular social experience (cf. Dresch and James 2000: 7). One method for achieving this goal is to live with the local population (Epstein 1967). Accordingly I wanted to live with the local Swahilis, who account for the majority of the population. It was my presumption that by residing with a Swahili family I would acquire a social place and identity within that environment, and thus more easily observe and participate in their daily lives and in their interactions with other members of their community. Furthermore, living with a Swahili family seemed a good way to improve my Kiswahili language skills over a short period of time. However, my attempts at acquiring such a residence failed.

All the Swahili Zanzibaris with whom I discussed the possibility of living for the duration of my stay in Zanzibar politely turned down my proposition. I initially stayed at a hotel in Zanzibar town, which was owned by an Asian. The manager, Issa, an African who had recently arrived from the mainland, was assigned the task of helping me with the residence dilemma. Again, we visited a few Swahili homes, but without success. Issa was astonished by my desire to live with a Swahili family, and pointed out that if I was a 'white' European, this task of finding a residence would be easy (as I also learned from the experiences of other European researchers in Zanzibar) but because I was Asian, it was extremely difficult. Swahili Zanzibaris are reluctant to trust Asians (see Larsen 2004: 134), and given that I was perceived primarily as an Asian, my options were quite limited. This failure to acquire residence with a Swahili family was my first apprenticeship in the field, but I was not aware of this until much later. Finally, with no success in this endeavor, I had to seek alternative arrangements.

Accepting defeat and feeling pessimistic about being able to pursue my fieldwork in the way I had planned, I resigned myself to residing with an Asian family, and thus began my second apprenticeship in the field - not by choice, but by virtue of the identity assigned to me. To make matters worse, acquiring recognition as an academic researcher also proved to be problematic. For many Zanzibaris with whom I interacted, only a white person fit the description of a researcher and thus, associating someone who was Asian at the level of these white individuals did not make sense. I attempted to distinguish myself as a researcher to challenge this view, but overwhelmingly found that as far as they were concerned, I was a local Asian, and was treated as such.

Being cornered into this position, I had to accept the place that I was granted in society. However, over a period of time, as the frustrations of being powerless calmed and I acquired a better understanding of the freedom accessible in this social space, I was able to start comprehending the structure of local ethnic and racial relations. Though frustrated by the restrictions, this newly found knowledge led me to come to terms with my designated position, and eventually enhanced my ability to interact 
more strategically with the non-Asian population. Being around local Asians, I became aware that since they have historically had better access to various economic resources on the islands, they perceive themselves as having higher social status than the local Swahilis. Thus they controlled the space of social interactions with the Swahilis in the business environment. Since I was recognized as a local Asian, my initial interaction with Swahili Zanzibaris was framed by these controlled public spaces, which were accessible to everyone. Many Asians today also own hotels and restaurants and other tourist-based businesses in which many Swahili Zanzibaris work. Having the privilege of interacting amongst Asians, I was able to interact with their employees, creating the space I needed to pursue my research.

Through this interaction with Swahilis, new social spaces and networks emerged for meeting and interacting with other non-Asian Zanzibaris. This form of interaction also facilitated my ability to access new apprenticeships and consequently, with each new encounter, learn more about different aspects of the identity discourse in Zanzibar. Though caught in this power struggle, and holding a marginal position in it, the apprenticeships that came with this position allowed me to eventually develop the ability to achieve the objectives with which I came to Zanzibar. On reflection, if I had attempted to break the norms of this society upon arriving in the field and had managed to acquire residence with a Swahili family, I would have been marginalized by the local Asian community and treated suspiciously by the Swahilis. This sentiment was shared by several Asian and non-Asian respondents. Only by accepting a certain place given to me in Zanzibar society, or rather, by gaining an understanding of my place amongst Asians of Zanzibar was I able to later move through the local landscape and acquire various apprenticeships in the field. I did not seek these particular apprenticeships, but by nature of the role designated to me in these different social settings, these apprenticeships helped me understand how things were done.

Given that presentation of one's self to the people one studies influences the collection and interpretation of data in the field (cf. Caplan 1993: 178, GangulyScrase 1998: 44), an important aspect of my ability to conduct fieldwork and gather different kinds of data was based on my own position in this multi-ethnic landscape. Since I was perceived as a local, I had the opportunity (once I had understood the advantages of my position) to move and penetrate through different levels of social interaction between the different ethnic groups in Zanzibar. The ability and inability to interact with different groups of people enabled me to explore and comprehend the different layers of Zanzibar society.

While my social interaction with non-Asian Zanzibaris was dictated by my perceived identity as a local Asian, my position within the confines of the Asian community was shaped by my identity as an Ismaili, ${ }^{1}$ my religious faith. Local Asians identified me first and foremost as an Ismaili. At this level of segmentation within the society, in social spaces that were inaccessible to non-Asian Zanzibaris, my identification as an Ismaili governed the nature of my interaction with members of different Asian communal groups. An established identity as an Ismaili in one social space facilitated the construction of my identity as an Asian in another. These identities then allowed me to develop different forms of social relations with non-Asian Zanzibaris. This

\footnotetext{
${ }^{1}$ The Ismailis are a Shia sect within Islam. The majority of the members of the Ismaili community in Zanzibar are of Asian origin, though there has been some degree of intermarriage in the past ten to twenty years, incorporating Swahili Zanzibaris within this religious community. Ismailis are one of many Asian sectarian communities in Zanzibar (see Gregory 1993a, 1993b).
} 
allowed me to experience the level of structural distance between different religious and ethnic communities at different levels of society. Furthermore, although I had a limited knowledge of Kiswahili when I first arrived in Zanzibar, I was easily able to communicate with my Asian respondents in English and in Gujurati, an Indian language that is also my mother tongue, and so this unwanted identity allowed me to continue with my fieldwork.

Through my interaction, first with Ismailis and then other Asians, I was able to rely upon them and their social networks to introduce me to non-Asian Zanzibaris. Without establishing a defined place amongst the Ismailis, it would have been difficult to develop social relations with other Asians and then, with non-Asians. As I became confident with my language ability and became familiar with more non-Asian Zanzibaris, I ventured through different parts of town to meet with people who were affected by the changes brought forth by tourism. Not only the Asians, but also the Swahili and Arab Zanzibaris that I subsequently met, became a source of contact and reference when I was trying to meet new people. These networks opened up new opportunities for interacting with other Zanzibaris, but in respect for their status my ability to interact with various other groups of people at different times was restricted. For example, on occasions when my Asian friends saw me in the company of Swahili respondents, they were very polite in interacting with them, but later complained that I was spending too much time with the Swahili. My Swahili friends never made such comments, at least not to me. In another instance, some respondents found my action of interviewing a Swahili prostitute who catered to the tourists near a brothel problematic. They argued that since I was associated with them, my presence in such environments and with persons considered to have no morality diminished their own status and respectability.

Constrained by these expectations and responsibilities, I had to learn to plan strategically my daily movement through different parts of town, so that I could stay in contact with all my respondents, Asians and non-Asians alike. At the same time, I had to maintain and respect the existing structural distances that divide the different ethnic and social groups. Acquiring knowledge of my respondents' daily movement pattern over a period of months enabled me eventually to figure out where and when I could expect to meet the different respondents. I eventually developed a schedule which ensured that the times and places at which I was meeting Swahili friends did not overlap with my commitments to Asian friends, thus not creating awkward situations for anyone. I accommodated my movement according to their daily routines and only on rare occasions did situations arise, where my movement was in conflict with my perceived social position in different social spaces.

Having acquired (quasi) local status, expectations of me from those who made up my 'community' (Ismailis and Asians) were the same as those of all others in that community. In their view, I was a local Asian and was expected to act accordingly. It did not matter that being a researcher I needed to have greater freedom to explore various activities associated with my research. Initially, the Asian Ismaili Muslims were the only ones who welcomed me into their community, and thus, I was expected to obey their rules of membership. As their networks facilitated my movement, my research agenda had to remain secondary to the position and the boundaries defined for me by their community.

Despite the trials and frustrations I experienced by being labeled as a local Asian my affiliation with the Asian community turned out to serve as a point of strength. Over 
the course of my stay in Zanzibar, I was recognized and treated as a local in most social spaces, something that many white, European researchers or for that matter, most anthropologists would have been unable to achieve. Thus I was able to move between the realms of being an 'outsider' and an 'insider'. Moving as a local exposed me to the underlying racial tensions dividing different ethnic groups in Zanzibar and boundaries that divide different public and private spaces. Knowledge of these boundaries and the marginal position that different ethnic groups occupy provided key insights for investigating how different Zanzibaris are struggling to move today from their designated positions in society. Furthermore, as tourism alters existing social practices and introduces new ones, awareness of how Zanzibaris relate to each other illustrates how the ability to develop new economic dispositions within the tourism environment transforms their position in society and facilitates the constructions of new identities.

\section{Politics of positionality}

Apprenticeships are shaped by the access that a researcher acquires to enter different social spaces. Consequently, the knowledge constructed through these apprenticeships highlight the different realms of power within a society. The position of the researcher in the fields shaped within this discourse. My perceived identity as a local Asian dictated my interaction with the local population and when that identity was transformed, so was my ability to acquire different kinds of knowledge. This point is well illustrated in one particular experience in Zanzibar. While in the field, a white female friend from Oxford, who was working on a project in Dar es Salaam, came to visit me in Zanzibar. Given the local gender dynamics instituted by the practice of Islam in Zanzibar, I had to insist to my friend that she could not stay at my house, though that would have been perfectly acceptable back in the UK. She visited me during the Muslim fasting month of Ramadan. Coincidently, Zanzibar was also plagued by a cholera epidemic at that time, leaving it void of most tourists. After receiving her at the seaport we walked through Stone Town to her hotel, for which I had made arrangements prior to her arrival. However, as we wandered through the narrow streets of Stone Town, beach boys, ${ }^{2}$ locally known as paapasi (a derogatory term for these young men which translates as 'cockroaches'), desperately looking for some business, continuously harassed us, trying to persuade her to stay at one hotel or another. With the lack of tourists around, we could not escape. We finally made arrangements with one beach boy to take us to Prison Island, a small island about three miles from Stone Town, which has become a popular snorkelling spot for tourists. Making this arrangement with one beach boy and walking in his company provided us with the freedom to move around more freely, without being bothered by other beach boys.

On the way out to Prison Island later that day, the beach boy as well as four of his friends and the owner of the boat accompanied us. As the boat sped away from the harbour area, I served as a tour guide for my friend, giving her a crash course on the history of Zanzibar. We were immersed in our conversation and the beach boys were involved in theirs. In the middle of the twenty-minute boat journey to Prison Island,

\footnotetext{
${ }^{2}$ The term, 'beach boy' is used by all locals and tourists alike to refer to a category of young men, aged between 16-35 who, being unemployed, follow tourists around in order to offer them various services such as finding a hotel, places to eat, and sites to visit, for a nominal fee.
} 
one of the beach boys started speaking to me in Kiswahili. Having been in the field for about six months now, my Kiswahili had drastically improved but was by no means good enough to engage in a slang conversation with a beach boy. I responded that I knew limited Kiswahili. The beach boy reacted to this by insisting that I was an Mhindi, a local Asian Zanzibari, and was just trying to impress the white woman and take business away from them (something to which they did not look kindly). Before I knew it, we went back and forth arguing, in Kiswahili and English, about the fact that I was not a local Asian, but I was unable to convince them. Then, one of the beach boys demanded that I prove what I claimed. Feeling bemused, I did not know what to do and turned to my friend for assistance. She asked me if I had any documentation. Immediately, I took out a photocopy of my US passport from my wallet and passed it to one of the beach boys for examination. Immediately, he turned around to others and blurted, 'Yeye ni mzungu' ('He is a white person'). ${ }^{3}$ Within a matter of minutes, I had gone from being a local Asian man to being perceived as a white European. Interestingly enough, I had never considered myself either. The beach boys, by virtue of the power they possessed in this space of social interaction, set up a distinct category to perceive my identity and when proven otherwise (with 'documentation'), I was moved to another. Upon accepting that that I was not a local Asian, their behaviour towards me also became a bit friendlier.

This incident, as well as other issues discussed above, point to the significance of local power relationships in shaping the ability of the researcher to move through the local landscape and acquire a local identity and place within the society. Before leaving for the field, I had never given consideration to issues of power that might arise in the field. Trained in various quantitative and qualitative methods for data collection and having learnt techniques for being proficient in 'participant observation', I found myself completely unprepared to face the realities of the field. In anthropological fieldwork methodology, much emphasis is placed on the process of participant observation. I had every intention to pursue this method, but found myself at a loss when the community neither wanted me to participate in nor observe their lives. Over time, I learned that my respondents, Asians and non-Asians alike, possessed the power to dictate what social spaces I could access. Based on this experience, I argue that apprenticeships in the field are shaped more by those who actually allow the researcher to enter their lives rather than by the researcher's fieldwork agenda. These apprenticeships make it possible to gather an awareness of the position(s) in which members of the society consider the presence of the researcher acceptable. Through my first apprenticeship, I quickly learned, and thankfully at the beginning of my fieldwork, where my presence was not necessarily welcomed. Only after coming to terms with this assigned position was I able to develop the means to explore new avenues for pursuing my research objectives. In this field of contending discourses, where unequal power relationships shape different types of social interaction, anthropologists, regardless of how important they may consider their presence in the field, remain at the mercy of their hosts, or rather those willing to take on the role of hosts.

\footnotetext{
${ }^{3}$ My translation. While mzungu could mean many different things, the only context in which I have heard beach boys use the word mzungu is to refer to white Europeans.
} 


\section{Conclusion}

The pursuit of fieldwork involves constantly moving between different social spaces in which the researcher develops various apprenticeships. As this movement is taking place, the researcher has to constantly negotiate their position between the different spaces in which they are moving. Being part of this politicized field in Zanzibar by means of my racial and ethnic identity, my position required accepting the prevailing racial biases that governed my movement. Through constant negotiation of my (marginalized) place in these different spaces, the knowledge emerging from the different apprenticeships allowed me to develop the means to move through the local social landscape, as I had originally desired. While perceived as a local Asian, I could never, by virtue of not being a local Asian, internalize the position of a local Asian. However, through the knowledge I acquired in this apprenticeship as a local Asian, I learned about the people and places that were acceptable for me (as an Asian) to visit. In the presence of Asians, I maintained those values, but in their absence, and once I was able to establish a position as a researcher and a non-local Asian with other Zanzibaris, the nature of the social relationships with the individuals involved dictated my movement. In all instances, despite being perceived as a local Asian, I remained, in my view, at the mercy of those who agreed to interact socially with me.

For every researcher, the issue of power relationships with regards to positionality within the local community is an important aspect of fieldwork. The power we perceive ourselves to possess, as anthropologists, regardless of our racial and/or ethnic origins, is very different from the perception held of us in the communities we enter to conduct fieldwork and the position in which we may end up while in the field. The positions we acquire in the field will directly reflect the power relations in the community and the degree of power we possess in this process. The nature of various apprenticeships establishes the different sets of power relationships and dictates the kind of information we acquire in the field. While these power relationships are different in every social setting, an ability to understand one's place within them, I strongly believe, is vital for being able to conduct fieldwork effectively. Most likely, there may not be an academic course one can take before leaving for the field to master this issue and each ethnographic setting is unique with its own set of problems, but by discussing it, as I have attempted to do here, we can learn to acknowledge this issue and develop an awareness of it. Consequently, when entering the field with this knowledge, we are better able to negotiate our movement through the local landscape and more easily able to access various apprenticeships for conducting fieldwork.

\section{References}

Caplan, P. 1993. Learning gender: fieldwork in a Tanzanian coastal village, 1965-85. In Gendered fields: women, men and ethnography (eds) D. Bell, P. Caplan \& W.J. Karim, 168-81. London: Routledge.

Castells, M. 2001. The power of identity. Oxford: Blackwell.

Dresch, P. \& W. James. 2000. Introduction: fieldwork and the passage of time. In Anthropologists in a wider world: essays on field research (eds) P. Dresch, W. James \& D. Parkin, 1-26. Oxford: Berghahn.

Epstein, A.L. 1967. The craft of social anthropology. London: Tavistock. 
Fordham, G. 1998. Participant observation and language learning. In Research methods in the field: eleven anthropological accounts (eds) M. Crick \& B. Geddes, 16-43. Geelong, Victoria: Deakin University Press.

Ganguly-Scarse, R. 1998. The self as research instrument. In Research methods in the field: eleven anthropological accounts (eds) M. Crick \& B. Geddes, 44-65. Geelong, Victoria: Deakin University Press.

Gregory, R.G. 1993a. South Asians in East Africa: an economic and social history, 1890-1980. Oxford: Westview.

Gregory, R.G. 1993b. Quest for equality: Asian politics in East Africa, 1900-1967. London: Sangam Books.

Hetherington, K. 1996. Identity formation, space, and social centrality. Theory, Culture and Society 13 (4): 33-52.

Jenkins, T. 1994. Fieldwork and the perception of everyday life. Man 29: 433-55.

Keshodkar, A. 2004. Movement of Asian and Swahili identities: impact of tourism on constructions of community, ethnicity, and gender relations in Zanzibar Town. D. Phil thesis to be submitted to Institute of Social and Cultural Anthropology, University of Oxford.

Larsen, K. 2004. Change, continuity and contestation: the politics of modern identities in Zanzibar. In Swahili modernities: culture, politics and identity on the East Coast of Africa (eds) P. Caplan \& F. Topan, 121-43. Trenton, New Jersey: Africa World Press.

\section{About the author}

Akbar Keshodkar is presently in the final stages of completing his $\mathrm{PhD}$ in social anthropology at Oxford University. His dissertation examines the impact of tourism on the Asian and Swahili identity discourse in Zanzibar, Tanzania. His wider research interests include exploring effects of globalization on expressions of Islam and the Muslim identity in East Africa. 